\title{
Proses Sosialisasi dan Komunikasi Planned Organizational Change PTAM Giri Menang kepada Karyawan
}

\author{
Andariesta Adhani Panggita \\ Media dan Komunikasi, Universitas Airlangga, Universitas Airlangga \\ Jalan Dharmawangsa Dalam No. 4-6 Surabaya 60286, Indonesia. \\ Email: andariesta.adhani@gmail.com
}

\begin{abstract}
Change is an integral part of organization life-phase. The change that occurred in an organization doesn't necessarily only affect the external parts but also the internal sphere of an organization as well. To ensure organization can tackle this change communication is required to aid the information circulation or socialization of the internal sphere and assist the employees on the process of interactions as their mean to understand and interpret the change that happened in the organization. In the beginning of 2020, PT. Air Minum Giri Menang which was a municipally owned company changed into a municipally owned company based on limited liability company. This change certainly brings significant effects to the company's internal sphere. The purpose of this research is to provide an overview of how the internal communication strategy implemented by PTAM Giri Menang in socializing the changes to the employees. The method used in this research is qualitative descriptive method. The result of the research indicates that the change occurred in the PTAM Giri Menang Company subsequently affect the internal sphere of the organization. These changes is categorized as a Planned Organizational Change and subsequently brought up the misperception and misunderstanding perceived by the employees. Senior employees particularly experienced strong and unpleasant response, even pushing for employee's restructuration. Organization was forced to create better communication strategy to better cope with this particular situation.
\end{abstract}

Keywords: Organization Communication; Internal Communication; Socialization; Organization Change; Planned Organizational Change.

\begin{abstract}
ABSTRAK
Suatu perubahan dapat terjadi dalam berbagai aspek kehidupan masyarakat, tidak terkecuali pada ranah organisasi. Perubahan yang terjadi pada suatu organisasi pun tidak serta merta hanya berdampak pada lingkup eksternal saja. Namun, perubahan yang terjadi juga sangat berpengaruh di dalam lingkup internal suatu organisasi yang mengalami perubahan. Pada tahun 2020 lalu, PT. Air Minum Giri Menang yang sebelumnya merupakan perusahaan berbasis Perusahaan Daerah harus berubah menjadi sebuah perusahaan daerah berbasis Perseroan Terbatas (PT). Perubahan tersebut memberikan dampak yang signifikan di dalam internal perusahaan. Tujuan dari penelitian ini adalah untuk memberikan gambaran bagaimana komunikasi internal PTAM Giri Menang dalam Mensosialisasikan Perubahan Organisasi PTAM Giri Menang kepada Karyawan. Adapun metode yang digunakan dalam penelitian ini adalah metode deskriptif kualitatif. Hasil penelitian menunjukkan bahwa terjadi perubahan pada perusahaan PTAM Giri Menang yang berdampak pula terhadap perubahan internal perusahaan. Perubahan tersebut dikategorikan sebagai Planned Organizational Change. Perubahan tersebut memunculkan perbedaan makna yang dipahami oleh para karyawan. Muncul reaksi-reaksi karyawan khususnya pada karyawan lama atas dan berdampak pada restrukturasi karyawan. Sehingga, terjadi pula perbedaan strategi yang dilakukan oleh tim manajemen dalam mengkomunikasikan dan mensosialisasikan perubahan organisasi tersebut.
\end{abstract}

Kata kunci: Komunikasi Organisasi, Komunikasi Internal, Sosialisasi, Perubahan Organisasi, Planned Organizational Change.

\section{A. PENDAHULUAN}

Dalam membangun atau menciptakan organisasi pun kita menyadari bahwa kita tidak dapat melakukannya seorang diri. Untuk menjalankan organisasi, kita juga tidak dapat 
menjalankan sesuai keinginan masing-masing individu tanpa melihat atau mendengar pendapat orang lain di dalam organisasi. Sehingga perlu untuk menciptakan satu kesepakatan atau budaya jangka panjang dalam menjalankan organisasi yang juga secara tidak langsung akan berdampak pada upaya menyatukan perbedaan-perbedaan dari setiap individu di dalam organisasi. Terbentuknya kesepakatan-kesepakatan di dalam organisasi tersebut turut serta menggunakan proses komunikasi. Namun, tidak dapat dipungkiri bahwa organisasi pasti akan mengalami perubahan-perubahan, entah karena mengikuti perkembangan zaman atau bahkan karena situasi-situasi yang mendesak dan mengharuskan terjadinya perubahan pada organisasi.

Di dalam dunia kerja, perubahan juga tidak bisa dihindarkan. Dalam situasi-situasi tertentu, perusahaan pasti akan dihadapkan dengan adanya situasi yang pada akhirnya mengharuskan terjadinya beberapa atau bahkan seluruh aspek dalam suatu organisasi mengalami perubahan. Perubahan tersebut nyatanya juga terjadi pada PTAM Giri Menang. PTAM Giri Menang merupakan perusahaan air minum daerah untuk wilayah Kota Mataram dan Kabupaten Lombok Barat yang secara resmi mengalami perubahan dalam status badan hukum perusahaannya pada Februari tahun 2020 berdasarkan Peraturan Daerah (Perda) Kabupaten Lombok Barat Nomor 2 tahun 2019 tentang Perusahaan Perseroan Daerah Air Minum Giri Menang. Aturan tersebut berada dibawah amanat aturan Undang-Undang Nomor 23 Tahun 2014 tentang Pemerintah Daerah dan Peraturan Pemerintah Nomor 54 Tahun 2017 tentang Badan Usaha Milik Daerah.

PTAM Giri Menang awalnya berstatus Perusahaan Daerah (PD), yang kemudian berubah menjadi Perseroan Terbatas (PT). PTAM Giri Menang menjadi perusahaan air minum daerah pertama yang diwajibkan untuk beralih menjadi Perseroan Terbatas (PT) sekaligus menjadi contoh bagi perusahaan air minum daerah lainnya. Aturan daerah tersebut mengubah dan mengatur sistematika perusahaan secara keseluruhan sesuai dengan bagaimana sebuah perusahaan perseroan terbatas yang juga berdampak pada internal perusahaan. Hal-hal yang diatur mulai dari kepemilikan saham dan penentu keputusan atas aset dan saham, perubahan struktur organisasi secara keseluruhan dari bagian tertinggi hingga internal perusahaan, perubahan nama perusahaan, dan perubahan nama jabatan di dalam internal perusahaan.

Dari perubahan tersebut kemudian dilakukan perombakan kembali pada internal perusahaan mulai dari struktur organisasi, perubahan nama jabatan, perubahan dan penambahan bagian atau divisi di dalam perusahaan, terjadinya mutasi karyawan secara besar-besaran dan proses pemberhentian pada para karyawan yang memang seharusnya sudah masuk masa pensiun. Hal tersebut akhirnya juga berpengaruh pada penambahan jumlah karyawan baru bagi perusahaan berdasarkan perubahan status dan struktur perusahaan saat ini. Mutasi karyawan terjadi didasarkan pada kualifikasi karyawan lama yang kemudian dipindahtugaskan pada divisi yang sesuai dengan kualifikasi dan kemampuannya tersebut baik di internal kantor pusat maupun dialihkan pada kantor-kantor cabang PTAM Giri Menang. Penambahan jumlah karyawan juga dilakukan untuk mengisi kekosongan formasi tiap-tiap bagian dan juga mengisi formasi bagian-bagian baru yang ada pada internal perusahaan.

Terjadinya perubahan pada PTAM Giri Menang secara menyeluruh tersebut tentu harus dikomunikasikan dan disosialisasikan kepada seluruh karyawan, baik kepada karyawan lama maupun kepada karyawan baru agar tercipta sebuah kesepakatan atau pemahaman yang baru dan sama. Adapun maksud dari penelitian ini adalah untuk mengetahui dan mengkaji bagaimana komunikasi internal organisasi yang dilakukan oleh PTAM Giri Menang dalam mensosialisasikan perubahan organisasi kepada para karyawan. Wang \& Liu (2009) 
mengatakan bahwa komunikasi organisasi merupakan sesuatu yang penting dalam performa manajemen (Kheirandish et al., 2017).

Secara tradisional, komunikasi organisasi adalah proses penciptaan makna dari interaksi-interaksi di organisasi (Pace et al., 2018). Berdasarkan definisi fungsi, komunikasi organisasi dikatakan sebagai penafsiran atas pesan-pesan di antara unit-unit komunikasi yang juga bagian dari organisasi. Pantam dalam Havoo et al (2005) mengatakan bahwa dalam kajian riset komunikasi organisasi secara psikologi dan kebiasaan, terdapat tiga pilar komunikasi verbal yaitu public speaking, persuasi, dan kajian riset berkaitan dengan komunikasi lainnya seperti komunikasi personal, kelompok maupun massa (EBRAHIMI et al., 2014)

Komunikasi organisasi sebenarnya berkaitan dengan suatu analisis atau kajian dari berbagai interaksi di dalam suatu sistem. Sistem ini dinamakan sistem komunikasi organisasi. Mengutip dari Irawan \& Venus (2006), organisasi memiliki ciri khas yang saling berhubungan antara satu dengan yang lainnya berdasarkan bagaimana arus interaksi atau proses komunikasi dalam pengorganisasiannya (Murti et al., 2017). Pace et al. (2018)menjelaskan bahwa sistem tersebut berkaitan dengan bagaimana komunikasi menjelaskan pesan-pesan dari banyak orang pada waktu, kondisi, dan situasi yang sama, yang mana masing-masing memiliki jenis hubungan interaksi yang berbeda pula (Pace et al., 2018).

Hal-hal yang terkait dengan perilaku, pikiran, dan keputusan diatur dalam satu aturan bersama dan tentu memiliki perbedaan dalam setiap gaya mengkomunikasikan pesan maupun cara memimpin dalam organisasi. Motivasi yang terbangun juga tentu berbeda-beda, yang tentu saja juga sangat dipengaruhi oleh iklim komunikasi di dalam organisasi yang terjadi. Dari segi tingkat kepuasannya pun berbeda. Tingkat kepuasan mempunyai indikator berdasarkan kecukupan informasi yang didapat melalui jenis, bentuk dan metode komunikasi yang berbeda, yang mana memanfaatkan tingkat materi dan energi untuk berkomunikasi yang efektif.

Sebagaimana yang telah dipaparkan sebelumnya dalam definisi komunikasi organisasi, pembentukan persepsi atau makna melalui pesan-pesan yang disampaikan di dalam organsasi disesuaikan atau berdasarkan bagaimana proses komunikasi yang membawanya. Sehingga, dapat kita simpulkan bahwa di dalam organisasi banyak komponen komunikasi yang meliputinya.Agustini \& Purnaningsih (2018) menjelaskan bahwa proses komunikasi yang terjadi di dalam organisasi merupakan bagian dari yang dinamakan dengan komunikasi internal (Agustini \& Purnaningsih, 2018). Trajkova et al. (2014) menjabarkan bahwa di dalam komunikasi organisasi, terdapat empat aliran dalam komunikasi organisasi yang sangat perlu untuk diperhatikan. Pertama, yaitu aliran komunikasi vertikal yang mana komunikasi yang terjalin antara manajer dengan pekerja. Dijelaskan bahwa pada aliran komunikasi vertikal ini, terdapat sub aliran komunikasi yang meliputi yaitu komunikasi upward dan komunikasi downward (TRAJKOVA et al., 2014).

Aliran komunikasi horizontal adalah komunikasi yang terjalin diantara sesama pekerja atau seseorang dengan jabatan atau posisi unit atau divisi yang setara dengan seseorang lainnya. Aliran komunikasi horizontal ini dijelaskan sangat berguna dan membantu para pekerja untuk saling terbuka dan memudahkan koordinasi terhadap tugas-tugas yang keterkaitan pada setiap divisi atau unit di dalam organisasi.

Aliran komunikasi diagonal merupakan suatu aliran komunikasi yang mampu secara efektif dan meminimalisir waktu menghubungkan para pekerja dengan seseorang atau divisi yang berbeda level atau tingkatan dengan mereka maupun dengan para pekerja lainnya yang berada pada unit organisasi yang lainnya. Terakhir adalah aliran komunikasi informal yang mana dapat membantu para anggota di dalam suatu organisasi untuk mentransfer atau 
mendistribusikan pesan-pesan atau informasi-informasi secara informal. Aliran komunikasi informal tersebut juga memandang yang namanya sikap dan perilaku. Hal ini berpengaruh terhadap bagaimana proses penerimaan pesan atau informasi yang kemudian juga dilandasi oleh perasaan, emosional, dan lainnya di dalam diri individu.

Di antara keempat aliran komunikasi yang telah dijabarkan tersebut kemudian memang yang paling sering menonjol dalam kajian komunikasi organisasi adalah aliran komunikasi vertikal dan horizontal. Pace et al. (2018) menjabarkan bahwa komunikasi ke bawah atau komunikasi downward diartikan dengan proses aliran informasi dari atasan untuk mengkomunikasikan pesan atau informasi kepada bawahan berupa tahapan-tahapan dalam pengerjaan tugas, diskusi terkait dengan pekerjaan, penyebaran informasi mengenai kebijakan-kebijakan, dan informasi mengenai penilaian terhadap performa atau kinerja para pekerja terhadap tugas-tugas (Pace et al., 2018). Selanjutnya komunikasi ke atas atau komunikasi upward diartikan sebagai komunikasi yang dimulai dari bawah ke atas dan juga sangat diperlukan di dalam sebuah organisasi.

Tujuan dari adanya komunikasi upward tersebut adalah untuk memberikan ruang kepada bawahan dalam menyampaikan hal-hal atau informasi yang memang perlu disampaikan dan didengar oleh atasan seperti memberitahukan terkait progres dari suatu pekerjaan, penyampaian terkait dengan masalah-masalah dan hal-hal lainnya yang kiranya memang perlu disampaikan secara langsung oleh para pekerja kepada atasan. Evelina \& Angeline (2014) menyimpulkan bahwa pada intinya, aliran komunikasi keatas sifatnya cenderung berkaitan dengan suatu permohonan atau pendapat ataupun opini yang di utarakan oleh pekerja (Evelina \& Angeline, 2014). Sedangkan aliran komunikasi kebawah sifatnya cenderung berkaitan dengan suatu pesan atau informasi yang disampaikan atasan kepada bawahan yang tujuannya untuk dilakukan atau dilaksanakan.

Dalam mengatasi perubahan organisasi, jajaran petinggi atau atasan tidak dapat begitu saja langsung mengkomunikasikan dan melakukan perombakan tanpa diketahui oleh para karyawan. Mengkomunikasikan perubahan yang terjadi pada organisasi memerlukan persiapan yang lebih matang mulai dari mengkaji secara rinci perubahan organisasi yang terjadi, mengkomunikasikan dengan melakukan sosialisasi, dan bagaimana menangani reaksi atas penerimaan informasi di kalangan para pekerja atau karyawan. Perubahan organisasi nyatanya banyak terjadi dan dilakukan oleh atasan dalam suatu organisasi.

Hakim \& Sugiyanto (2019) mengatakan bahwa hal tersebut dikarenakan adanya permasalahan-permasalahan atau krisis internal yang ditemukan dalam organisasi seperti masalah keuangan, sumber daya manusia, operasional dan lainnya (Hakim \& Sugiyanto, 2018). Dalam ranah organisasi publik, Dewi \& Kurniawan (2019: 55) juga mengatakan bahwa perubahan tidak dapat langsung dilakukan. Terdapat hambatan-hambatan yang pasti akan muncul dalam prosesnya yaitu suatu penolakan atau resistensi. Lebih lanjut dijelaskan bahwa penolakan tersebut akan muncul disebabkan oleh rasa ketidaksesuaian realita yang terjadi dengan sesuatu yang diharapkan.

Perubahan organisasi secara umum didefinisikan sebagai suatu langkah yang diambil oleh atasan dalam menghadapi krisis atau permasalahan, baik secara disengaja maupun tidak disengaja. Model Planned Organizational Change yang dikemukakan oleh Connor \& Lake (1994) menjelaskan bagaimana proses perubahan-perubahan yang terjadi di dalam suatu organisasi atau perusahaan terjadi secara terencana (Miller, 2012). Perubahan organisasi yang direncana tersebut dirancang atau didesain untuk membangun suatu budaya atau sistem baru di dalam organisasi atau perusahaan dengan berbagai alternatif perencanaan sebagai bagian dari upaya mengeksplorasi atau mengembangkan organisasi kearah yang lebih baik lagi. Hasil dari perencanaan organisasi yang baru tersebut kemudian disebarkan kepada para karyawan dan diimplementasikan ke dalam aktivitas sehari-hari organisasi. 
Baakari et al. (2017) juga menjabarkan bahwa model kepemimpinan juga memberikan pengaruh terhadap proses dari perubahan termasuk yang sifatnya perubahan terencana atau Planned Organizational Change (Baakari et al., 2017). Hal ini berhubungan dengan bagaimana suatu perubahan yang terjadi di dalam suatu organisasi tidak hanya memberikan makna atau persepsi terkait dengan perubahannya, tetapi juga bagaimana para anggota juga memaknai atau membentuk persepsi mengenai kepemimpinan seseorang atas perubahan yang terjadi di dalam organisasi. Lebih lanjut Baakari et al. (2017) menjelaskan bahwa persepsi para anggota organisasi tersebut dapat dikaji dari suatu proses integrasi antara model Planned Organizational Change dengan Three Step model yang dikemukakan oleh Lewin's (Baakari et al., 2017). Hasil integrasi tersebut kemudian akan membentuk sebuah aturan yang perlu diperhatikan dari persepsi para anggota mengenai proses perubahan di dalam organisasi. Adapun Three Step model yang dikemukakan oleh Lewin's digambarkan dalam gambar bagan sebagai berikut:

Gambar 1. Model Tiga Tahap dalam membangun persepsi dari terjadinya perubahan organisasi.

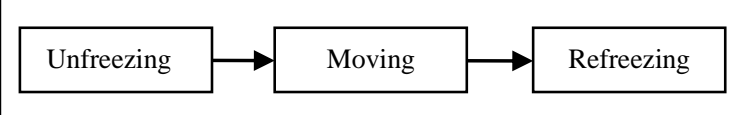

Sumber: (Baakari et al., 2017)

Clampitt, DeKoch,\& Cashman (2000) menyajikan kategori-kategori strategi komunikasi yang dapat dilakukan oleh atasan ataupun organisasi dalam mengkomunikasikan perubahan organisasi (Miller, 2012). Kategori-kategori yang dijabarkan tersebut cenderung didominasi oleh kategori strategi komunikasi perubahan yang berkaitan dengan strategi komunikasi top-down. Penjabaran kategori strategi komunikasi perubahan tersebut dijabarkan oleh Clampitt, DeKoch, \& Cashman (2000) dalam bentuk tabel di bawah ini:

Tabel 1.1. Strategi Komunikasi Organisasi Top-Down

\begin{tabular}{|c|c|}
\hline Strategi & Definisi \\
\hline Spray and Pray & $\begin{array}{c}\text { Manajemen memberikan banyak informasi kepada anggota organisasi dengan } \\
\text { harapan anggota organisasi dapat memilah mana informasi yang penting dan } \\
\text { tidak penting }\end{array}$ \\
\hline Tell and Sell & $\begin{array}{l}\text { Manajemen memilih beberapa informasi yang berkaitan dengan inti dari } \\
\text { masalah organisasi. Kemudian manajemen "memberitahu" anggota organisasi } \\
\text { dan "menjual" anggota organisasi berdasarkan pada pendekatan yang dipilih }\end{array}$ \\
\hline $\begin{array}{c}\text { Underscore and } \\
\text { Explore }\end{array}$ & $\begin{array}{c}\text { Manajemen fokus pada isu-isu dasar mengenai kesuksesan perubahan dan } \\
\text { memberikan kebebasan terhadap kreatifitas anggota organisasi untuk } \\
\text { mengembangkan berbagai kemungkinan }\end{array}$ \\
\hline Identify and Reply & $\begin{array}{c}\text { Manajemen mendengarkan dan mengidentifikasi masalah utama anggota } \\
\text { organisasi dan langsung merespon masalah tersebut }\end{array}$ \\
\hline
\end{tabular}


Withhold and

Uphold
Manajemen menahan berbagai informasi dan membangun gerakan dalam menghadapi pertanyaan-pertanyaan atau desas desus yang menyebar mengenai organisasi ataupun perubahannya

Sumber: (Miller, 2012)

Perubahan organisasi tentu tidak akan dapat diterima secara langsung oleh seluruh jajaran di dalam perusahaan termasuk para karyawan. Tentu terdapat reaksi-reaksi yang tidak diharapkan oleh perusahaan yang muncul di dalam organisasi. Reaksi-reaksi tersebut biasanya berupa reaksi atau tindakan keluhan atau penerimaan yang kontra dengan apa yang menjadi tujuan dan harapan perusahaan atas terjadinya perubahan organisasi. Reaksi-reaksi yang muncul pada umumnya berupa permasalahan-permasalahan yang menjadi dilema baik bagi perusahaan maupun bagi karyawan yang kemudian harus segera ditindaklanjuti agar tidak menjadi hambatan bagi proses perubahan serta tidak menimbulkan permasalahan yang lebih besar dan meluas. Covin, T.J. \& Kilmann, R. H. (1990) mengurutkan permasalahanpermasalahan yang muncul ketika terjadinya perubahan organisasi (Miller, 2012). Adapun kategori tersebut diurutkan sebagai berikut:

Gambar 2. Kategori permasalahan yang Teridentifikasi dalam Perubahan Organisasi.

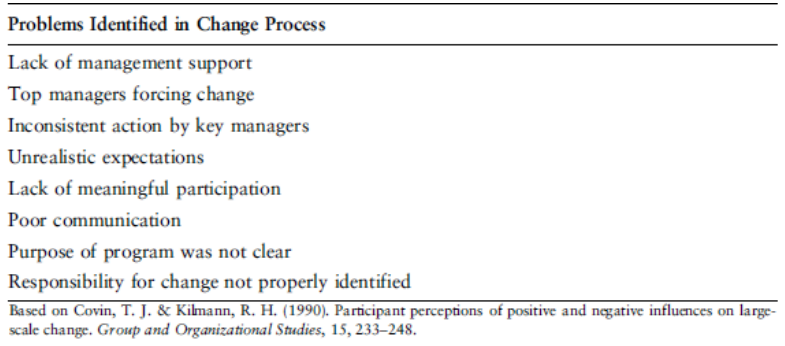

Sumber: (Miller, 2012)

Dalam menghadapi dan menangani perubahan-perubahan sangat disadari oleh organisasi bahwa tidak hanya sekedar bagaimana komunikasi dan strategi-strategi dalam proses penanganan dampak dari terjadinya perubahan organisasi. Tetapi perusahaan atau organisasi tentu juga perlu memikirkan bagaimana langkah atau tahapan selanjutnya dari penanganan proses perubahan. Komunikasi perubahan juga sangat berkaitan dengan bagaimana perusahaan atau organisasi memberikan sosialisasi terkait perubahan organisasi. Mensosialisasikan hal-hal yang terjadi di dalam perusahaan termasuk terjadinya perubahan dan bagaimana prosedur dari perubahan yang baru sangatlah penting dilakukan oleh perusahaan. Hal tersebut membantu perusahaan atau organisasi meminimalisir terjadinya bias informasi dan menjadikan perusahaan atau organisasi lebih transparan.

Proses sosialisasi di dalam perusahaan atau organisasi juga dapat dijadikan sebagai proses interaksi timbal balik yang berkelanjutan antara perusahaan dengan karyawan atau organisasi dengan anggota dalam upaya membentuk pemahaman atau kesepakatan yang sama. Proses sosialisasi tidak hanya diperuntukkan bagi anggota atau karyawan yang kiranya sudah lama berada di dalam sebuah perusahaan atau organisasi. Tetapi proses sosialisasi juga memiliki peran yang penting bagi para anggota atau karyawan yang baru. Proses sosialisasi bagi karyawan atau anggota baru sangat diperlukan untuk menginformasikan terkait dengan gambaran maupun berbagai informasi mengenai organisasi atau perusahaan yang perlu 
diketahui oleh karyawan atau anggota baru sehingga mereka dapat dengan cepat beradaptasi dengan lingkungan dan budaya dari perusahaan atau organisasi.

Proses sosialisasi menurut Jablin \& Krone (1987) berhubungan dengan proses individualisasi dimana organisasi berperan dalam upaya mempengaruhi anggota organisasi melalui pemberian banyak informasi yang bertkaitan dengan organisasi untuk menyamakan persepsi dan tujuan yang sesuai dengan organisasi (Miller, 2012). Namun di sisi lain, anggota organisasi juga memiliki peran atau kuasa dalam menggerakkan proses individualisasinya untuk berdaptasi dengan lingkungan dan budaya organisasi seperti menyesuaikan diri dengan sistem kerja dan aturan-aturan yang telah ada di dalam organisasi.

\section{B. METODE PENELITIAN}

Pendekatan yang digunakan dalam penelitian ini adalah pendekatan kualitatif yang mana menurut Bogdan \& Taylor (1992) bahwa pendekatan kualitatif diharapkan mampu menghasilkan suatu penjelasan yang mendalam mengenai ucapan, tulisan, dan perilaku yang dapat diamati dari suatu individu, kelompok, masyarakat, organisasi tertentu dalam suatu konteks atau kondisi tertentu. Pada intinya, pendekatan kualitatif memiliki ciri-ciri (1) menjelaskan fenomena, (2) inner behavior, yaitu melihat perilaku yang berasal dari dalam, (3) holistik, yaitu bersifat menyeluruh (Ruslan, 2013).

Pendekatan kualitatif digunakan karna diyakini mampu memberikan jabaran secara detail fenomena atau isu yang diangkat peneliti. Perubahan organisasi tentu akan memungkinkan memunculkan respon-respon di dalam internalnya yang juga tentu membutuhkan proses penggalian informasi secara mendalam dikarenakan respon-respon tersebut tak jarang sangat berpengaruh terhadap sisi personal individu ataupun cenderung bersifat pribadi dan tertutup.

Metode yang digunakan dalam penelitian ini adalah metode deskriptif kualitatif yang bertujuan untuk menjelaskan suatu fenomena berdasarkan data yang faktual, sistematis, dan akurat dengan maksud menggali makna yang lebih mendalam (Kriyantono, 2020). Metode deskriptif kualitatif diyakini mampu memberikan jabaran yang faktual dalam menggali makna terkait dengan bagaimana perubahan organisasi dimaknai oleh para karyawan dan bagaimana komunikasi internal yang dilakukan oleh perusahaan dalam mengkomunikasikan perubahan organisasi berdasarkan konsep Planned Organizational Change dan proses sosialisasi yang dijelaskan oleh Miller (2012).

Penelitian ini berfokus pada permasalahan mengenai bagaimana langkah-langkah PTAM Giri Menang sebagai perusahaan air minum daerah untuk wilayah Kota Mataram dan Kabupaten Lombok Barat dalam mengkomunkasikan dan mensosialisasikan perubahan perusahaan yang menimbulkan dampak pada internal perusahaan yang dirasakan oleh seluruh karyawan. Sehingga, penelitian dilakukan pada kantor pusat PTAM Giri Menang pada bulan Maret 2020.

Adapun metode pengumpulan data pada penelitian ini adalah dengan menggunakan metode pengumpulan data secara kualitatif berdasarkan Sugiyono (2018) yaitu wawancara mendalam dan studi dokumentasi. Wawancara secara mendalam atau in-depth Interview merupakan sumber data primer dalam penelitian ini dan dilakukan untuk mewawancarai informan terkait dengan penelitian. Wawancara digunakan mendapatkan data-data yang dibutuhkan dengan lebih akurat (Sugiyono, 2018). Data sekunder dalam penelitian ini berupa data-data atau dokumentasi terkait dengan masalah penelitian yang peneliti ambil dari perusahaan dan dapat melengkapi data primer. Studi dokumentasi merupakan catatan peristiwa yang berupa tulisan, gambar dan segala hal bentuk dokumentasi lainnya yang menjadi pelengkap data dalam proses pengumpulan data (Sugiyono, 2018). 


\section{HASIL DAN PEMBAHASAN}

Hasil penelitian menunjukkan bahwa perubahan status yang terjadi pada perusahaan PTAM Giri Menang berdampak pada segala hal di dalam internal perusahaan.

"Perubahan status ini tentu berdampak ke semua hal di dalam internal perusahaan mulai dari struktur yang mana nama jabatan atau posisi berubah dari kepala bagian menjadi manajer, kemudian ada beberapa divisi yang baru dan juga diganti, kemudian ada karyawan yang cukup banyak untuk dipindah tugaskan ke divisi lain dan bahkan ke anak-anak perusahaan lainnya. Untuk budaya organisasi, di perubahan yang baru ini kita lebih ingin membangun suasana dan sistem kerja seperti perusahaan-perusahaan berbentuk PT pada umumnya" (I (29 th) Kabid Hukum, indepth interview, 12 Maret 2020).

Berdasarkan jawaban di atas, dapat disimpulkan bahwa perubahan status badan hukum PT. Air Minum Giri Menang menimbulkan dampak yang besar pada struktur perusahaan, tugas karyawan, dan budaya organisasi yang berubah karena disesuaikan dengan budaya perusahaan PT. Dalam perubahan Organisasi menurut Connor \&Lake (1994) terdapat model Planned Organizational Change yang mana perubahan tersebut terjadi karena adanya aturan pemerintah yang memang sudah dicanangkan dari lama kemudian berdampak besar di dalam lingkungan internal perusahaan (Miller, 2012).

Gambar 3. Model Perubahan Organisasi Planned Organizational Change.

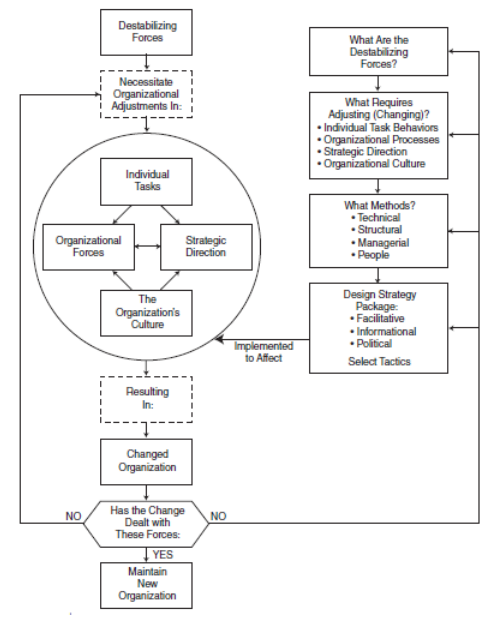

Sumber: Miller (2012)

Berdasarkan gambar di digambarkan bahwa model perubahan organisasi ini diawali dari adanya ketidakstabilan di dalam organisasi yang kemudian menyebabkan organisasi melakukan penyesuaian-penyesuaian pada kebiasaan atau perilaku individu, arah strategis, kekuatan dan proses organisasi, dan budaya organisasi yang menghasilkan perubahan organisasi. Apabila perubahan tersebut telah dapat menangani ketidakstabilan organisasi sebelum mengalami perubahan maka selanjutnya organisasi melakukan penguatan dan 
pengelolaan terhadap perubahan organisasi agar dapat diterapkan. Apabila perubahan tersebut belum bisa menangani ketidakstabilan organisasi, maka, harus dilakukan penyesuaianpenyesuaian kembali berdasarkan analisis mengenai (1) penyebab terjadinya ketidakstabilan, (2) hal-hal yang harus diperhatikan untuk diubah (kebiasaan individu, proses organisasi, arah strategis, dan budaya organisasi), (3) metode-metode yang digunakan, (4) strategi yang dilakukan untuk proses perubahan organisasi.

Berdasarkan hasil penelitian yang ditemukan dan dikaitkan dengan model perubahan organisasi tersebut, dijelaskan bahwa ketika timbul reaksi atau adanya ketidaksetujuan terhadap perubahan organisasi, maka perlu kembali dilakukan analisis terkait dengan (1) penyebab terjadinya ketidakstabilan, (2) hal-hal yang harus diperhatikan untuk diubah (kebiasaan individu, proses organisasi, arah strategis, dan budaya organisasi), (3) metodemetode yang digunakan, (4) strategi yang dilakukan untuk proses perubahan organisasi. Hal tersebut menjadi langkah-langkah dalam menangani reaksi-reaksi yang timbul dan disesuaikan dengan komunikasi apa yang efektif dilakukan agar kemudian reaksi dapat mereda dan timbul penerimaan atas perubahan organisasi.

Berdasarkan model tiga tahap Lewin's (Baakari et al., 2017) perubahan terencana yang dilakukan PTAM Giri Menang dapat dijabarkan sebagaimana pada tahap pertama, yakni unfreezing yang mana merupakan proses awal dari sebuah perubahan dan proses awal bagi para karyawan serta perusahaan untuk mengidentifikasi mengapa harus terjadi perubahan, seberapa perlu perubahan dilaksanakan, dan bagaimana kesiapan perusahaan serta karyawan dalam melakukan perubahan. Dapat dikatakan pada tahap ini perusahaan melakukan pemetaan terhadap penyebab dan kemungkinan-kemungkinan yang timbul ketika proses perubahan terjadi. Tidak hanya itu, dalam hal sikap dan reaksi juga diantisipasi oleh perusahaan di tahap ini. seberapa mungkin para karyawan mampu menerima dan berkontribusi dalam proses perubahan dipetakan oleh perusahaan dalam tahap unfreezing.

Pada tahap kedua yakni moving yang mana dimaksudkan sebagai proses lanjutan dari tahapan sebelumnya. Proses moving ini adalah proses dari berlangsungnya perubahan. Dan para karyawan memberikan reaksi mereka sekaligus membangun kembali komitmenkomitmen yang mereka jalani sesuai dengan aturan ataupun sistem baru yang diterapkan oleh perusahaan. Pada intinya, tahap ini merupakan tahap bagaimana perusahaan dan karyawan berusaha menerima terjadinya perubahan di dalam organisasi ataupun perusahaan. Tahap terakhir, yakni refreezing adalah suatu proses yang menggambarkan suatu penerimaan pada akhirnya dapat diintegrasikan dengan perubahan. Para karyawan dan juga perusahaan secara keseluruhan masuk pada tahapan adaptasi dengan perubahan yang terjadi di dalam organisasi atau perusahaan. Pada intinya, ketika para karyawan sudah mampu menerima dan perusahaan juga sudah mampu untuk melakukan perubahan, tentu hal selanjutnya adalah membangun atau membentuk ulang segala hal yang berkaitan dengan organisasi tersebut sesuai dengan yang direncanakan.

Pada saat perubahan status diumumkan, tidak dapat dipungkiri bahwa terjadi reaksi yang cukup kuat oleh para karyawan.Berdasarkan hasil identifikasi diatas, reaksi karyawan yang terjadi akibat dari perubahan status badan hukum PT. Air Minum Giri Menang dimulai dari kategori reaksi unrealistic expectationsyang dirasakan oleh karyawan yang kemudian menyebabkan ketidaksetujuan atau lack of meaningful participation.

"Reaksi ini timbul setelah di uji coba alih tugas yang pertama oleh manajemen pasca perubahan. Merekamengeluhkan ketidakpuasan mereka langsung ke direksi masing- 
masing mengenai tugas yang mereka rasa tidak sesuai." (I (29th) Kabid Hukum, indepth interview, 12 Maret 2020).

Reaksi unrealistic expectations yang dimaksud berdasarkan hasil penelitian adalah baik karyawan maupun perusahaan memiliki ekspektasi atau harapan yang berbeda dari terjadinya perubahan organisasi yang perlu dikomunikasikan. Ketidaknyamanan yang dirasakan beberapa karyawan PTAM Giri Menang dalam proses adaptasi perubahan sistem perusahaan disebabkan oleh ketidaksesuaian ekspektasi antara yang diharapkan oleh karyawan dengan realita yang diterima karyawan. Apa yang mereka terima dianggap oleh karyawan sebagai sesuatu yang tidak realistis sehingga perlu ditemukan kejelasan dan keterbukaan dari pihak manajemen perusahaan. Reaksi tersebut tentu juga memungkinkan munculnya reaksi atau permasalahan lain seperti poor communications dan purpose of program was not clear. Hal tersebut dikarenakan tim manajemen perusahaan kurang baik dalam mengkomunikasikan perubahan yang terjadi dan harus dihadapi oleh karyawan. Penanganan atas perubahan juga dianggap karyawan kurang atau belum maksimal dikarenakan penyampaian informasinya yang belum lengkap dan belum bisa membuat karyawan dengan cepat menerima atau menyepakati perubahan organisasi.

Reaksi selanjutnya yang juga cukup dominan terjadi berdasarkan hasil temuan penelitian adalah reaksi lack of meaningful participationsyaitu akibat adanya ekspektasi karyawan yang tidak sesuai dengan apa yang mereka terima, sangat memungkinkan para karyawan yang merasakan ketidaksesuaian tersebut kemudian berkontribusi dalam perubahan secara setengah-setengah atau bahkan tidak berkontribusi sama sekali. Hal tersebut juga sangat memungkinkan menjadi salah satu tindakan mereka dalam upaya menyuarakan ketidaksetujuan dan ketidaknyamanan yang mereka rasakan agar dapat didengar dan ditindaklanjuti segera oleh perusahaan.

Menangani berbagai reaksi yang muncul tersebut, tim manajemen khusus perusahaan yang memang dibentuk untuk menangani proses transisi langsung sigap menanggapi, mengelola, dan kemudian memutuskan penanganan dari adanya berbagai reaksi tersebut.

"Setelah kita mendengarkan langsung keluhan karyawan, akhirnya dilakukan Alih tugas yang kedua. Proses tersebut terjadi selama seminggu saja." (I (29th) Kabid Hukum, indepth interview, 12 Maret 2020).

Seperti yang dikatakan oleh informan yang bahwa selain melakukan proses negosiasi dan perundingan dengan beberapa karyawan yang memiliki keluhan terkait perubahan di dalam organisasi, tim manajemen khusus perusahaan juga melakukan proses alih tugas yang kedua dimana diharapkan dari adanya proses alih tugas sesi kedua ini, para karyawan yang sebelumnya tidak atau belum merasa puas dengan pemindahan posisi maupun tugas pada akhirnya mampu beradaptasi dan menyesuaikan diri dengan lebih nyaman.

Artinya proses alih tugas yang kedua ini diharapkan menjadi jawaban yang tepat maupun penanganan yang tepat yang dilakukan oleh perusahaan. Karyawan kemudiam mendapatkan apa yang menjadi ekspektasi atau harapan mereka dari terjadinya perubahan terhadap internal perusahaan. Berdasarkan hasil penelitian, setelah tim manajemen khusus PTAM melakukan proses adaptasi alih tugas yang kedua, berbagai reaksi dari karyawan yang sebelumnya banyak muncul di tahap satu kemudian mereda dan teratasi dengan baik. Dapat 
diartikan bahwa telah terjadi penerimaan dan kesepakatan yang sama-sama menguntungkan antara perusahaan maupun karyawan terhadap perubahan yang terjadi pada internal PTAM. Pada akhirnya kondisi internal perusahaan pun juga menjadi lebih kondusif.

Perubahan status PTAM Giri Menang apabila dilihat berdasarkan strategi top-down Clampitt, DeKoch, dan Cashman (2000), tim manajemen khusus PTAM Giri Menang menggunakan dua strategi komunikasi dalam menghadapi perubahan dan penanganan atas reaksi-reaksi yang muncul dari karyawan yaitu strategi komunikasi Tell \& Sell dan juga strategi komunikasi Identify \& Reply (Miller, 2012). Strategi komunikasi Tell \& Sell digunakan oleh tim manajemen khusus PTAM dalam proses menginformasikan perubahan status kepada para pegawai. Tim manajemen tidak membatasi informasi yang diberikan. Berbagai informasi juga tidak ambigu atau bukan sesuatu hal yang digunakan untuk menutupi apapun berkaitan dengan penyebab terjadinya perubahan. Tim manajemen perusahaan secara terbuka menginformasikan perubahan kepada karyawan.

Kemudian, tim manajemen PTAM Giri Menang melanjutkan penanganan reaksi dengan menggunakan strategi Identify \& Reply. Ketika timbul reaksi dari para pegawai seperti yang telah disampaikan sebelumnya,tim manajemen khusus PTAM secara terbuka dan langsung mendengarkan dan mengambil langkah-langkah untuk segera menangani berbagai reaksi yang muncul tersebut. Tim manajemen menindaklanjuti berbagai reaksi tersebut dengan mengidentifikasi apa yang menjadi penyebab munculnya reaksi atau rasa tidak terima yang dirasakan oleh karyawan. Kemudian hasil keputusan untuk menangani reaksi-reaksi yang ada dikomunikasikan secara langsung kepada para karyawan melalui proses alih tugas kedua sebagai proses adaptasi bagi para karyawan yang belum dapat menerima perubahan di sesi pertama.

Berdasarkan hasil penelitian, diketahui bahwa proses sosialisasi atas perubahan status pada PTAM Giri Menang kepada karyawan dimulai dengan menginformasikan mengenai perubahan, kemudian dilakukan mutasi karyawan sebagai rancangan alih tugas pertama yang telah diputuskan oleh tim manajemen. Alih tugas tersebut dirancang sesuai dengan budaya perusahaan berbasis PT. Secara bersamaan dengan proses perubahan status, perusahaan juga melakukan perekrutan karyawan baru untuk mengisi kekosongan-kekosongan posisi yang ada di dalam perusahaan. Seperti yang telah disampaikan oleh informan bahwa ada dampak lain yang timbul akibat dari perubahan status yaitu diadakan proses regenerasi pegawai yang juga dilakukan secara bersamaan dengan proses perubahan status tersebut.

"Itu merupakan dampak dari perubahan ini. Karena ada perubahan, dan pas juga kita melihat lagi masa kerja pegawai senior yang sudah cukup banyak untuk pensiun, ada beberapa divisi baru juga sebagai efek dari perubahan, kita adakanlah perekrutan untuk proses regenerasi pegawai." (I(29th) Kabid Hukum, indepth interview, 12 Maret 2020).

Informan lainnya juga menambahkan bahwa yang terkena dampak perubahan tidak hanya karyawan lama saja, tetapi juga karyawan baru. Mutasi pada karyawan baru juga dilakukan mengingat adanya divisi-divisi baru yang hadir setelah internal organisasi berubah sesuai dengan strukturasi dan budaya dalam sebuah perusahaan PT.

"Perubahan itu juga terjadi di saat proses perekrutan karyawan juga selesai. Karyawan baru pun ada yang terkena dampak dari perubahan tersebut." (M (27th) karyawan baru divisi SDM, indepth interview, 12 Maret 2020) 
Proses tersebut menimbulkan yang dinamakan proses asimilasi. Menurut Jablin \& Krone (1987) organisasi berusaha mempengaruhi anggota organisasi dengan memberikan banyak informasi mengenai organisasi untuk menyamakan tujuan dalam organisasi (Miller, 2012). Namun, di sisi lain anggota organisasi juga menggerakkan proses individualisasinya untuk berdaptasi dengan lingkungan organisasi seperti menyesuaikan diri dengan sistem kerja dan aturan-aturan yang telah ada di dalam organisasi. Para karyawan berusahan diberikan penjelasan dan sosialisasi agar dapat menerima pemindah tugasan yang terjadi. Kemudian para karyawan juga tidak lantas mengenyampingkan sifat individualisnya yang siap melakukan proses adaptasi di tempat mereka yang baru. Proses adaptasi dan pengenalan diberlakukan agar kemudian terjadi pembentukan tim yang kompak dan solid.

Melihat sosialisasi yang dilakukan oleh perusahaan terhadap para karyawan, apabila dikaitkan dengan proses sosialisasi Menurut Miller (2012) dapat diidentifikasi sebagai berikut:

a. Sosialisasi antisipasi: Proses sosialisasi antisipasi merupakan sosialisasi yang terjadi sebelum seseorang masuk ke dalam organisasi. Dalam hal ini, hanya karyawan baru yang mendapatkan sosialisasi mengenai tugas-tugas dan organisasi dikarenakan hal tersebut menjadi salah satu hal yang penting dalam rangkaian proses perekrutan karyawan. Karyawan baru mendapatkan sosialisasi tersebut dalam agenda atau kegiatan orientasi yang diadakan perusahaan setelah proses seleksi perekrutan karyawan. Sementara pada karyawan lama, tidak ada proses sosialisasi yang sangat mendetail mengenai tugas-tugas terkait dengan posisi atau divisi mereka yang baru. Karyawan lama hanya berlandaskan dari aturan-aturan berkaitan tugas pokok yang sudah ada dan juga berdasarkan Struktur Organisasi Tata Kelola (SOTK) baru yang telah dirancang oleh perusahaan sesuai dengan perubahan status yang berlaku. Sehingga apabila ditelaah mengenai kesiapan karyawan dalam menghadapi perubahan, karyawan baru dapat dikatakan lebih siap menghadapi perubahan dibandingkan pegawai lama. Sehingga, proses alih tugas dijadikan tim manajemen PTAM sebagai sarana pelengkap dalam proses sosialisasi terkait dengan sistem internal perusahaan yang terbaru. Alih tugas tersebut dijadikan sebagai penanganan konflik serta proses sosialisasi perusahaan kepada karyawan, baik karyawan lama maupun karyawan baru agar tercipta tim-tim yang berdedikasi tinggi dalam hal kerjasama serta adaptasi.

b. Pertemuan: Proses sosialisasi Pertemuan digambarkan sebagai proses sosialisasi dimana anggota meninggalkan segala hal yang berkaitan dengan tempat kerjanya atau organisasi yang lama dan mulai beradaptasi dengan segala hal di tempat barunya atau organisasi barunya. Pada tahap ini, karyawan lama maupun baru PTAM Giri Menang harus meninggalkan kebiasaan-kebiasaan lama mereka di tempat atau divisi kerja sebelumnya. Namun, memang terjadi sedikit hambatan dalam proses meninggalkan kebiasaan lama pada lingkup karyawan lama. Hal tersebut ditandai dengan munculnya reaksi-reaksi tidak terima yang diutarakan oleh beberapa karyawan lama berdasarkan pada hasil penelitian dan pembahasan sebelumnya. Karyawanlama cenderung lebih susah untuk menerima keputusan dan kemudian meninggalkan kebiasaan-kebiasaan mereka di divisi atau bagian sebelumnya. Sedangkan karyawan baru lebih cepat dalam melakukan proses adaptasi dalam perusahaan. Walaupun beberapa karyawan baru juga terdampak pemindah tugasan atau posisi. Hal tersebut ditndai dengan tidak adanya reaksi-reaksi yang muncul yang disampaikan oleh karyawan baru. 
c. Metamorfosis: Proses sosialisasi metamorfosis adalah suatu gambaran bagaimana kedua tahapan sebelumnya telah selesai dilewati oleh anggota organisasi dan kemudian anggota secara aktif mulai bekerja di dalam suatu organisasi. Pada tahap proses sosialisasi ini, seluruh karyawan PTAM Giri Menang, baikkaryawan lama maupun baru pada akhirnya dapat menerima perubahan yang terjadi sesuai dengan apa yang menjadi harapan atau target perusahaan. Dapat diartikan bahwa karyawan sudah merasa nyaman dan menerima penempatan posisi beserta tugas pokok dan fungsinya yang dipilih atau diputuskan perusahaan. Sehingga kemudian seluruh karyawan dan tim manajemen dapat melanjutkan menjalankan perusahaan berdasarkan sistem dan status yang baru. sudah sesuai dengan kompetensi mereka.

Tiga tahapan proses sosialisasi yang dijabarkan oleh Miller (2012) menurut Singkoh (2013) adalah suatu gambaran dari sebuah proses dimana karyawan memiliki hak untuk mengidentifikasi berbagai hal yang diberikan perusahaan kepada mereka. Karyawan memiliki hak untuk menerima atau menolak sesuatu yang diberikan atau diperintahkan atasan kepada mereka (Singkoh, 2013). Ketika para karyawan sudah menyepakati untuk menerima apapun yang diatur di dalam sebuah perusahaan, mereka akan masuk kepada masa transisi atau proses adaptasi membentuk kebiasaan-kebiasaan baru yang disesuaikan dengan hal-hal baru yang juga mereka terima dan harus dijalani. Proses transisi tersebut mulai dirasakan oleh para karyawan ketika mereka telah memasuki tahap pertemuan yang kemudian dilanjutkan dengan tahapan metamorfosis.

Dalam upaya mengkomunikasikan informasi penting tentang perusahaan, tentu harus ada proses timbal balik yang diterima kedua belah pihak, baik komunikator maupun komunikan sebagaimana proses komunikasi didefinisikan. Dan proses timbal balik dalam komunikasi antara perusahaan dan karyawan juga sangat diperlukan. Sebagaimana yang telah dijabarkan dalam hasil penelitian dan pembahasan sebelumnya, apabila dilihat dari sisi perusahaan PTAM Giri Menang, proses komunikasi yang mendetail dan menghasilkan proses timbal balik dalam sosialisasi perubahan status kepada seluruh karyawan, baik karyawan lama maupun karyawan baru sedikit berbeda. Komunikasi dalam kaitannya proses sosialisasi yang dilakukan antara perusahaan dengan karyawan lama lebih menekankan pada bagaimana menangani dan mengedukasi kembali para karyawan terkait perubahan yang berlaku melalui penanganan reaksi karyawan atas perubahan status organisasi.

Dapat terlihat bahwa antara perusahaan dan karyawan lama terjadi interaksi atau komunikasi yang aktif dalam upaya menyamakan persepsi sesuai tujuan dan status perusahaan yang baru. Adanya pemberian informasi perubahan status yang kemudian memunculkan reaksi pada beberapa karyawan lama dan pada akhirnya ditanggapi kembali oleh perusahaan sehingga akhirnya mencapai kesepakatan yang selaras adalah bentuk dari proses komunikasi yang juga berlandaskan adanya timbal balik dalam proses sosialisasi yang dilakukan perusahaan. Setelah mensosialisasikan secara serentak, perusahaan juga melakukan sosialisasi secara personal kepada setiap karyawan agar reaksi yang bersebrangan dengan perusahaan mereda dan pada akhirnya tercipta keselarasan. Ini juga dapat dikatakan sebagai proses pendekatan secara personal yang dilakukan oleh perusahaan.

Sedangkan proses komunikasi antara perusahaan dengan karyawan baru lebih fokus pada penyampaian informasi-informasi mengenai perusahaan dengan sistem maupun status yang baru. Walaupun karyawan baru juga terdampak alih tugas, tetapi dari segi aturan, SOTK, budaya dan lingkungan kerja yang dihadapi sudah berlandaskan status PTAM Giri Menang yang baru. Sehingga tidak ada reaksi yang bersebrangan dengan perusahaan yang 
muncul dari para karyawan baru.Namun, hambatan yang mungkin dirasakan dari sisi karyawan baru adalah bagaimana kemudian sisi individualisnya mampu beradaptasi dengan lingkungan dan budaya perusahaan. Sebagai sosok yang baru di dalam internal suatu organisasi atau perusahaan, tentu sangatlah penting untuk dapat mengetahui dengan cukup detail terkait dengan lingkungan dan budaya di tempat kerja karena setiap organisasi maupun perusahaan tentu memiliki lingkungan dan budaya yang berbeda-beda.

"Mulai dari proses perekrutan sampai ketika saya berada dalam masa awal-awal mulai bekerja, saya terus mencari informasi mengenai perusahaan. Pada saat masa perekrutan, saya tentu mencari dan berusaha update tentang berbagai informasi seputar seleksi dan perekrutan karyawan. Saya mencari mulai dari website resmi, dari teman yang lebih dulu menjadi karyawan disini, dan juga saya dihubungi langsung oleh tim dari perusahaan." (R (23th) Karyawan baru divisi SDM, in depth interview, 12 Maret 2020).

Lebih lanjut disampaikan lagi oleh informan yang sama bagaimana tidak hanya pada saat proses awal saja ia mencari atau menggali informasi seputar perusahaan. Tetapi juga berlanjut ketika telah resmi bekerja dan menjadi karyawan baru di PTAM Giri Menang.

"Kemudian setelah secara resmi menjadi karyawan PTAM Giri Menang, tentu saya juga melakukan adaptasi baik dengan lingkungan maupun dengan rekan kerja saya. Saya berusaha mendekatkan diri dengan para karyawan baik karyawan lama maupun karyawan baru yang tujuannya adalah untuk mendapatkan informasi mengenai perusahaan dan membangun keakraban dengan sesama karyawan lainnya." (R (23th) Karyawan baru divisi SDM, in depth interview, 12 Maret 2020).

Miller, V. D. \& Jablin, F. M. (1991) mengklasifikasikan tujuh taktik yang memungkinkan dilakukan oleh anggota organisasi ketika berusaha mengumpulkan atau mencari informasi mengenai organisasi (Miller, 2012), yaitu: (1) Overt questions: Anggota atau pegawai baru mencari informasi dengan bertanya langsung, (2) Indirect questions: Anggota atau pegawai baru mencari informasi dengan bertanya menggunakan pertanyaanpertanyaan isyarat, (3) Third parties: Anggota atau pegawai baru mencari informasi dengan bertanya kepada sumber kedua, (4) Testing limits: Anggota atau pegawai baru mencari informasi dengan melanggar aturan organisasi dan mengamati reaksi, (5) Disguising conversations: Anggota atau pegawai baru mengumpulkan informasi dengan menyamarkan pencarian informasi dan berusaha sebagai bagian alami dari percakapan, (6) Observing: Anggota atau pegawai baru mengumpulkan informasi dengan mengamati perilaku dalam situasi yang menonjol, (7) Surveillance: Anggota atau pegawai baru mengumpulkan informasi dengan memahami perilaku yang diamati di masa lalu.

Berdasarkan hasil penelitian terhadap komunikasi dalam proses sosialisasi yang dilakukan oleh karyawan baru PTAM Giri Menang menunjukkan bahwa para karyawan baru hanya menggunakan beberapa taktik saja dalam mencari informasi. Pada karyawan baru, taktik yang digunakan dalam mengumpulkan informasi-informasi mengenai perusahaan yang berguna bagi dirinya adalah pertama, taktik overt questions yakni karyawan baru mencari informasi dengan bertanya langsung kepada internal perusahaan. Dalam hal ini bisa kepada tim manajemen langsung atau rekan kerja. Kedua, taktik disguising conversations karyawan 
baru mengumpulkan berbagai informasi seputar perusahaan dengan menyamarkan proses pencarian informasi menjadi sesuatu yang alami berupa percakapan-percakapan.

Pada lama, taktik yang digunakan untuk mendapatkan informasi yang lebih mendetail mengenai perubahan adalah taktik testing limits dimana pegawai mencari informasi dengan melanggar aturan organisasi dan mengamati reaksi. Reaksi atas perubahan dapat kita simpulkan sebagai suatu pemberontakan atau pelanggaran pegawai atas ketidaksesuaian yang mereka rasakan pasca perubahan. Dan kemudian menimbulkan reaksi di posisi perusahaan yang akhirnya membuat perusahaan menindaklanjuti keluhan atau pemberontakan mereka. Dibandingkan dengan pegawai lama, tentu menjadi hal yang wajar apabila pegawai baru lebih banyak menggunakan taktik untuk mengumpulkan informasi. Hal tersebut dikarenakan pegawai baru masih memiliki gambaran yang terbilang sedikit mengenai perusahaan.

\section{PENUTUP}

Perubahan organisasi yang terjadi di PTAM Giri Menang adalah perubahan status yang terencana karena adanya mandat wajib berubah oleh pemerintah berdasarkan aturan yang berlaku. Perubahan tersebut berdampak pada struktur, tugas karyawan, budaya, dan menimbulkan proses regenerasi karyawan. Sehingga dapat dikatakan bahwa perubahan status PTAM Giri Menang ini merupakan gambaran dari bagaimana sebuah organisasi atau perusahaan mengalami perubahan yang terencana yang harus dilakukan.

Proses sosialisasi PT. Air Minum Giri Menang atas perubahan status badan hukum perusahaan kepada pegawai lama dan pegawai baru memiliki perbedaan. Hal tersebut juga berdampak pada proses komunikasi yang terjadi dimana proses komunikasi perusahaan hanya bersifat menanggulangi reaksi yang dimunculkan oleh pegawai lama. Sedangkan pada pegawai baru, proses komunikasi perusahaan hanya berfokus pada bagaimana tim manajemen perusahaan menginformasikan mengenai rangkaian perekrutan pegawai dan identitas perusahaan yang baru. Namun, dalam hal kesiapan karyawan, dapat dikatakan bahwa karyawan baru lebih menunjukkan kesiapan dikarenakan berbagai informasi yang mereka terima merupakan gambaran perusahaan yang baru sesuai dengan perubahan yang baru. Sedangkan pada sisi karyawan lama memang lebih banyak terjadi proses negosiasi dari berbagai reaksi yang timbul atas perubahan. Artinya, dalam mencapai suatu penerimaan memang karyawan lama lebih membutuhkan proses yang cukup panjang.

Komunikasi Internal yang dilakukan oleh perusahaan dalam hal ini PTAM Giri Menang sudah cukup baik dalam menangani dan mengelola interaksi dengan para karyawan selama berlangsungnya proses perubahan status yang terjadi. Namun, memang dalam hal proses sosialisasi adaptasi terhadap status baru yang berlaku, ada baiknya perusahaan memberikan sosialisasi pelatihan secara menyeluruh kepada para karyawan, baik karyawan lama maupun karyawan baru agar lebih memaksimalkan penyesuaian dengan status baru yang berlaku serta tugas-tugas yang harus dijalani oleh para karyawan khususnya yang terkena dampak alih tugas akibat perubahan yang terjadi.

\section{DAFTAR PUSTAKA}

Agustini, N. A., \& Purnaningsih, N. (2018). Pengaruh Komunikasi Internal dalam Membangun Budaya Organisasi. Jurnal Komunikasi Pembangunan, 16(1), 2442-4102. https://doi.org/https://doi.org/10.46937/16201825198 
Baakari, H., Hunjra, A. I., \& Niazi, G. S. K. (2017). How Does Authentic Leadership Influence Planned Organizational Change? The Role of Employees' Perceptions: Integration of Theory of Planned Behavior and Lewin's Three Step Model. Journal of Change Management, 17(2), 1-33. https://doi.org/https://doi.org/10.1080/14697017.2017.1299370

EBRAHIMI, R., CHAMANZAMIN, M. R., \& SOURATI, P. (2014). Investigating the Effect of Organizational Communications on the Performance of Managers in Government Agencies of Astara. International Review of Management and Business Research, 3(4), 2095-2104.

Evelina, L. W., \& Angeline, M. (2014). Komunikasi Vertikal dan Horizontal dalam Membentuk Gaya Kepemimpinan Berbasis Kearifan Lokal: Studi pada Binus University. Humaniora, 5(1), 445-454. https://doi.org/https://doi.org/10.21512/humaniora.v5i1.3044

Hakim, L., \& Sugiyanto, E. (2018). Manajemen Perubahan Organisasi Sebagai Upaya Peningkatan Kinerja Perusahaan di Industri Batik Laweyan Surakarta. Jurnal Benefit, 3(2), 49-63. https://doi.org/https://doi.org/10.23917/benefit.v3i1.6562

Kheirandish, M., Avilagh, H. A., \& Nazemi, N. (2017). An empirical study of the pathology of organizational communications based on three branches model: A case study. Arab Economic and Business Journal, 12(2), 81-92. https://doi.org/https://doi.org/10.1016/j.aebj.2017.10.001

Kriyantono, R. (2020). Teknik Praktis Riset Komunikasi Kuantitatif dan Kualitatif: Disertai Contoh Praktis Riset Media, Public Relations, Advertising, Komunikasi Organisasi, Komunikasi Pemasaran (Edisi kedu). Kencana.

Miller, K. (2012). Organizational Communication: Approaches and Processes (M. Eckman \& R. Matthews (eds.); 6th ed.). Lyn Uhl.

Murti, R. A. M., Lestari, M. T., \& Ali, D. S. F. (2017). KOMUNIKASI ORGANISASI PT. PLN (PERSERO) AREA BANDUNG DALAM KEGIATAN CODE OF CONDUCT. Jurnal Kajian Komunikasi, 210-221. https://doi.org/https://doi.org/10.24198/jkk.v5i2.8487

Pace, R., Wayne, \& Faules, D. F. (2018). Komunikasi Organisasi : Strategi Meningkatkan Kinerja Perusahaan (Edisi 10). PT. Remaja Rosdakarya.

Ruslan, R. (2013). Metode Penelitian Public Relations dan Komunikasi (Edisi 6). PT. Rajagrafindo Persada.

Singkoh, C. J. (2013). PROSES SOSIALISASI SISTEM "SEMBILAN ALUR KERJA" DI PT.XYZ (EX CV.MNO). Jurnal E-Komunikasi, 1(1), 1-12.

Sugiyono. (2018). Metode Penelitian Kuantitatif, Kualitatif, dan R\&D. (Edisi kedu). Alfabeta.

TRAJKOVA, K., ANDONOV, M., \& MIHAJLOSKI, Z. (2014). Affective, Role of Organizational Communication on the Commitment. International Review of Management and Business Research, 3(1), 517-527. 